\title{
感染対策に関するボードゲームと講義による学習効果の比較に関する検討
}

\author{
川村ひとみ, ${ }^{a}$ 岸本桂子, ${ }^{*}, a$ 松田俊之, ${ }^{b}$ 福島紀子 $a$
}

\section{A Study on Comparison of Learning Effects between a Board Game and a Lecture about Infection Control}

\author{
Hitomi Kawamura, ${ }^{a}$ Keiko Kishimoto, ${ }^{*, a}$ Toshiyuki Matsuda, ${ }^{b}$ and Noriko Fukushima ${ }^{a}$ \\ ${ }^{a}$ Division of Social Phamacy, Faculty of Pharmaceutical Science, Keio University; 1-5-30

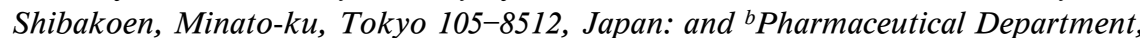 \\ Japan Labour Health and Welfare Organization, Yokohama Rosai Hospital; \\ 3211 Kozukue-cho, Kohoku-ku, Yokohama 222-0036, Japan.
}

(Received November 30, 2013; Accepted April 17, 2014)

\begin{abstract}
In order to provide an opportunity for community pharmacists to actively learn about infection control, this study created learning materials through a board game format and verified characteristics of learning by determining and comparing evaluation according to viewpoint and motivational effects between a lecture and the game. To create the board game, we collected cases of infection from 30 community pharmacists. The game was created using collected and created case studies, and we held a workshop on infection control. Participants were assigned to a lecture $(n=32)$ or game group $(n=27)$ and completed a questionnaire before and after the workshop. The questionnaire included the evaluation according to viewpoint based on the ministry's curriculum guidelines and the motivational effect of Keller's ARCS motivation model. In the evaluation according to viewpoint, the lecture group scores were significantly higher on "knowledge and understanding" than the game group scores. In the comparison of the motivational effects, the game group was significantly higher in three out of the four items of the ARCS motivation model, "Attention", "Relevance", and "Satisfaction". These results indicate that learning through the game aroused the curiosity of the learners, increased the learning outcome, and maintained certain levels of motivation. In addition, the evaluation according to viewpoint showed that the lecture group understood the key concepts and knowledge regarding infection control, whereas there was a possibility that the game group required additional motivational factors for learning and maintaining motivation level.
\end{abstract}

Key words_-game; pharmacist; infection control; educational effect

\section{緒言}

2009 年に発生した新型インフルエンザ大流行に おいて，薬局薬剤師は優先ワクチン接種対象者に含 まれなかった. 1) しかし，2013 年 6 月に作成された 「新型インフルエンザ等対策ガイドライン」²)におい て，特定接種の登録対象者に薬局薬剤師が含まれ, 薬局薬剂師は感染症患者に接する機会が多い医療従 事者の一人であると改めて示された。 大流行の経験 を通して薬局薬剤師らの感染対策への意識は向上し たが，その一方で，感染対策の知識や対応不足は改 善されていないと報告されている. ${ }^{3)}$ 医薬分業が進

The authors declare no conflict of interest.

$a$ 慶應義塾大学薬学部社会薬学講座, $b$ 独立行政法人労 働者健康福祉機構横浜労災病院薬剤部

*e-mail: kishimoto-ki@pha.keio.ac.jp
み，保険薬局には様々な感染症の患者が来局する. 薬局では患者の身体に直接触れる機会は少なく，患 者の滞在時間は比較的短いが，服薬指導では患者と 至近距離で向き合いながら行うことも多い. また, 薬局薬剤師の活躍の場は在宅訪問指導へも広がって きている. ${ }^{4)}$ そのため, 薬局薬剤師が感染対策のた めに必要な個人防護具や環境消毒等についての知識 を持つことは重要である。また，薬局薬剤師の感染 対策への意識・知識向上は, 地域住民への啓発や教 育にもつながると考えられる.

病院では，ICT の医師や看護師が中心となり， 感染対策の研修会で様々な取り組みが行われてい る. 院内全職員を対象とした感染の研修会の教育効 果5)や，感染対策研修会に参加している看護師は, 感染対策の基本である標準予防策に関する知識・態 度・実践に優れているとの調査結果6)が報告されて 
いる. しかし，感染対策の研修会は病院薬剤師向け が多く, 薬局薬剤師が感染対策について学ぶ機会は 少ないのが現状である．また，特に感染対策は状況 に応じた判断が必要となるため, 講義などの座学に より知識・スキルを獲得するだけではなく，実践的 な事例を用いた体験的な学習が重要であると考えら れる。体験的な学習を実現し，自己学習を促すこと ができる教材の 1 つとしてゲームがある.

ゲームは，以前に学習した知識を補強し，新たな 知識を獲得する機会への参加を促進する．また，繰 り返し行うことで重要な内容を反復して学ぶことが できるため，学習増進の効果があると考えられてい る.さらに，ゲームは理論と実践をつなぐことが可 能であり，即座にフィードバックの機会が得られ， 動機づけを増加させる。加えて，グループで行う ゲームは，学習者間の相互作用を促し，他者から学 ぶ機会を増やす。多くの他の教育形態と異なり, ゲームによる学習は，楽しさや好奇心をもたらし， 学習活動への参加を促進すると考えられている. ${ }^{7}$

そこで，感染対策について体験的な学習をする機 会を提供するため, 薬局薬剤師を対象としたボード ゲーム形式の教材を作成した。 また，ボードゲーム による学習の特徵を明らかにするために, 最も一般 的な学習法である講義と学習者にもたらす効果の違 いについて検討した。

\section{方法}

\section{1. ボードゲーム用事例問題の作成}

1-1. ボードゲームの概要ゲーム構成は，薬 局内で職員同士が対話しながら競争することで，感 染対策について能動的に思考し，知識を共有できる ように，事例検討型のすごろく形式のボードゲーム とした．ゲームは，株式会社モレーンコーポレーシ ヨンが開発した「SAVE」を薬剤師向けにアレンジ した.

「SAVE」は，看護師向けの感染対策教育ツール として開発された事例検討型のすごろく形式のボー ドゲームである。「CASEカード」に記載されてい る問題に対処するために必要な個人防護具等を $\lceil$ Key-item」から選び，解答しながら進めていく.

$\lceil\mathrm{CASE}$ カード」の問題は，実際に起きた事例を基 に作成されており，裏には問題に対する対応策が記 載されている，不正解の場合は，正解が出るまで次
の解答者に解答権が移る．正解者がこの対応策を読 み上げることで，参加者全員が知識を共有すること ができる，薬局薬剤師向けの「CASE カード」の問 題を作成し,「Key-item」の一部の変更を行つた。

1-2. 事例問題の作成「CASEカード」に記 載する問題を作成するため, 薬局薬剤師を対象とし たインタビュー調査を実施し，感染対策に関する体 験談や患者等から受けた問い合わせについての事例 を収集した。調査は，スノーボールサンプリング法 により，30 名に達するまで行った。

収集した事例は，感染症毎に分類し，事例に対す る対応を個人防護具，手指消毒，環境消毒の組合せ により類型化した，その後，シチュエーションが均 等になるよう配慮しながら，各感染症と各対応の組 合せ 1 パターンにつき 1 問作成した。解答は, Centers for Disease Control and Prevention (CDC) ガイドライン等を参考に作成し，感染制御専門薬剂 師 1 名と内容の正確性を確認した.

\section{2. 学習効果の評価}

2-1. 学習効果の測定複数の保険薬局を運営 する企業の協力を得て，ゲーム教材を用いた感染対 策に関する研修会の開催を勤務薬剤師に告知した。 研修会は，2013 年 9 月 6 日に実施した。参加者の 教育享受の倫理的観点から，ゲームと講義の両方を 受講できる研修構成とした（Fig. 1).

参加者を，(A) ボードゲームを講義に先行して実 施する群（以下，ゲーム群），(B) 講義をゲーム実施

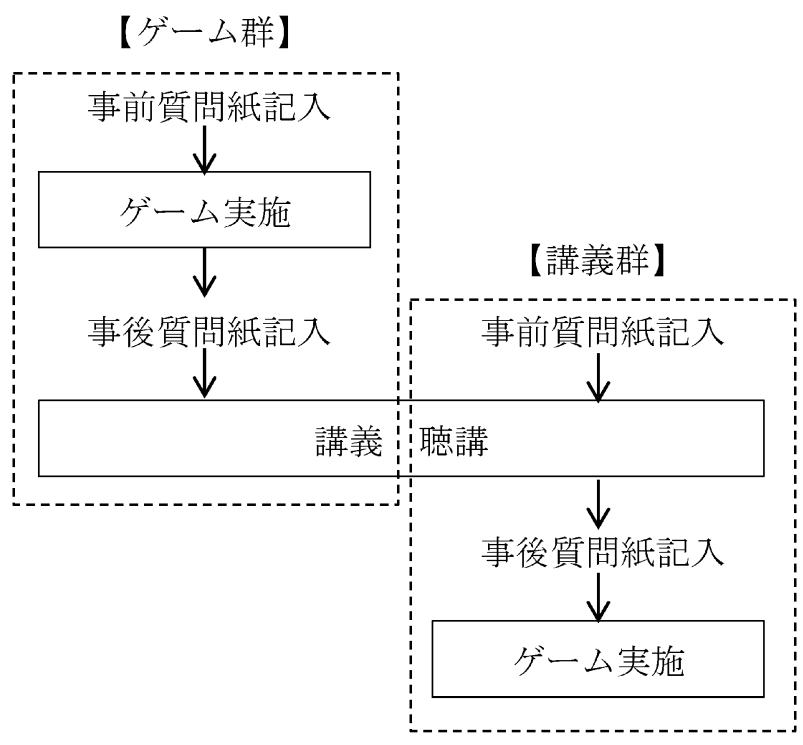

Fig. 1. Evaluation Procedure 
に先行して聴講する群（以下，講義群）の 2 群に振 り分け, 先行研究7-12) より, 各群 20-30 名とした. 振り分けは，参加希望者の参加可能な研修時間帯に 基づき行い， 2 群間で参加者の特性（性別，年齢， 薬剤師としての勤務年数）に差が生じないか確認 し，必要であれば調整することとした。なお，研修 の進行順序については研修当日に参加者に伝えた。

ゲーム群は，ゲーム教材実施前とゲーム教材実施 後に，講義群は，講義聴講前と聴講後に，それぞれ
質問紙に回答した。講義は，感染制御専門薬剂師 が，スライドを用い行つた。講義内容は，感染制御 専門薬剂師がゲームに用いた問題を基に作成し， ゲームでの学習内容と差が生じないように配慮し た。ゲームは 4 人 1 チームとし，ゲームと講義はと もに, 30 分間行った.

2-2. 質問紙の項目 使用した質問紙を Fig. 2-1 及び 2-2 に示す。質問紙の測定内容は，「観点別 評価」,「動機づけ効果」,「属性」とした.

\begin{tabular}{|c|c|c|c|c|c|}
\hline $\begin{array}{l}\text { ※ここで言う感染刘策」とは、「来局した感染症の患者 } \\
\text { さんへの対応や「在宅や施設での感染症の掋大防止 } \\
\text { などのことです。 }\end{array}$ & $\begin{array}{l}\text { ま全 } \\
\text { らく } \\
\text { なっ } \\
\text { いる }\end{array}$ & $\begin{array}{l}\text { な } \\
\text { な䭒 } \\
\text { ら }\end{array}$ & 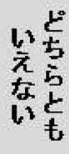 & $\begin{array}{l}\text { あ } \\
\complement \\
\text { 通 } \\
\text { ま } \\
\text { る }\end{array}$ & $\begin{array}{l}\text { あ } \\
\text { はと } \\
\text { まも } \\
\text { る }\end{array}$ \\
\hline 1. 感染対策に関心がある & 1 & 2 & 3 & 4 & 5 \\
\hline 2. 感染対策に関わりたい & 1 & 2 & 3 & 4 & 5 \\
\hline 3. 感染対策に対応できる & 1 & 2 & 3 & 4 & 5 \\
\hline
\end{tabular}

4. 空気感染の感染経路別予防策として必要だと思う個人防護具すべてによ印をつけてください (アメリリカ疾病管理予防ゼター (CDC)ガイドラインの感染別予防策を基準にお考えください)

ロ手袋・グローブロN95マスクロサージカルマスクロガウン・エブロン

5. 飛涑感染の感染経路別予防策として必要だと思う個入防護具すべてにょ印をつけてください (アメリリ疾病管理予防ゼター (CDC)ガイドライソの感染別予防策を基準(むお考えください)

ロ手袋・グローブ ロN95マスク ロサージカルマスク ロガウン・エブロン

6. 接触感染の感染経路別予防策として必要だと思う個人防護具すべてによ印をつけてください

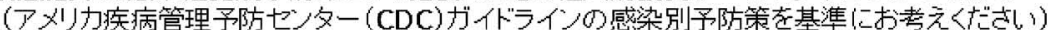

ロ手袋・グローブロN95マスクロサージカルマスクロガウン・エブロン

7. 水疱瘡(空気感染)に一罹患した子どもを親 (抗体(-))が看病するとき、気を付けた方が良いにと はありますか？と相談されました。親が使用する個人防護具、手洗、以外に、どのようなとと をアドハイイスしますか？下記に記述してください。

8. ロ多ウイルス(接触感染)に罹患した乳児のオムツを交換するとき(䔬口感染)、感染を広げない ために気を付けた方が良いことはありますか？と聞かれました。個入防護具、手洗い以外に、ど のようなととをアドノ゙イスしますか？下記に記述してください。

Fig. 2-1. Pre-questionnaire 
9. 藥局の受け付け事務さんに、イノフルエンザに罹患された患者さんが来局したときに(飛沫感染、

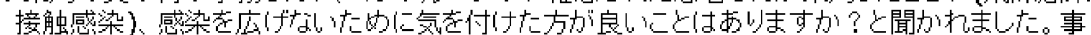
務員さんが使用する個人防護具、手洗い以外に、どのようなとをなド・゙イスしますか？下記に 記述してくだざい。

10. 感染对策について、どのような事を学びたいですか？

最後に、ご自身のことをお答えください

性別: 男 女

年齢: —歲

薬剂師としててい勤務年数: 年版

Fig. 2-1. (Continued)

「観点別評価」は，文部科学省「児童生徒の学習 評価の在り方について（報告）」13)に示されている, $「(1)$ 関心 ・ 意欲 - 態度」,「(2)思考 - 判断 - 表現」, 「(3)知識・理解」に基づいた内容とした。「(1)関心・ 意欲・態度」については，先行研究8-12) を参考に 3 項目 $[5$ 段階評価（1.全くあてはまらない〜 5. とて もあてはまる)］作成した． 5 段評価の值が大きい ほど関心，意欲，態度が高いことを示す.「(2)思考・ 判断・表現」については，ゲーム作成時に収集した
事例を参考に，現実に起こり得る問題を解決するた めの思考力等を評価する自由記述式問題 3 問とし た。問題解決として適切なアドバイス 1 記載を 1 点 とし，合計点を算出した。「(3)知識・理解」につい ては，CDCガイドラインを基準とし，感染対策の 基本的な知識である感染経路別個人防護具の選択に 関する 3 問を作成した。各問について正しい組み合 わせを解答している場合 1 点，不適切な組み合わせ を解答している場合 0 点とし，合計点を算出した. 


\begin{tabular}{|c|c|c|c|c|c|c|c|c|c|c|}
\hline \multicolumn{6}{|c|}{ 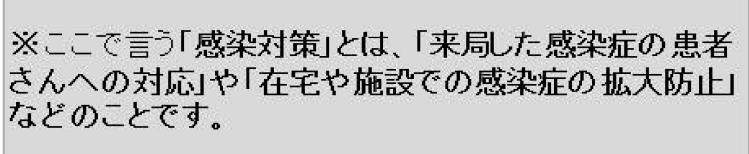 } & $\begin{array}{l}\text { ま全 } \\
\text { ら } \\
\text { な市 } \\
\text { い: }\end{array}$ & $\begin{array}{l}\text { な } \\
\text { いま } \\
\text { いま } \\
\text { ら }\end{array}$ & 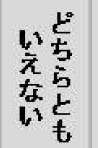 & $\begin{array}{l}\text { あ } \\
\zeta \\
\text { ほ } \\
\text { ま } \\
\text { る }\end{array}$ & $\begin{array}{l}\text { あ } \\
\text { 㔚 } \\
\text { まも } \\
\text { る }\end{array}$ \\
\hline \multicolumn{6}{|l|}{ 1. 感染对策に関心がある } & 1 & 2 & 3 & 4 & 5 \\
\hline \multicolumn{6}{|l|}{ 2. 感染对策に関わりたい } & 1 & 2 & 3 & 4 & 5 \\
\hline \multicolumn{6}{|l|}{ 3. 感染対策に対応できる } & 1 & 2 & 3 & 4 & 5 \\
\hline \multicolumn{11}{|c|}{ 今、受講した研修について下記の16項目を評価してぐさい。 } \\
\hline & $\begin{array}{l}\frac{\varepsilon}{c} \\
t\end{array}$ & + & 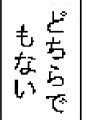 & 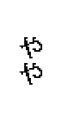 & $\begin{array}{l}\frac{k}{c} \\
t\end{array}$ & & & & & \\
\hline つまらなかった & & & & & & \multicolumn{5}{|c|}{ おもしろからた } \\
\hline 眠くなった & & & & & & \multicolumn{5}{|c|}{ 眠くならなかった } \\
\hline 好奇心をそそられなかかた & & & & & & \multicolumn{5}{|c|}{ 好奇心をそそられた } \\
\hline マンネリだった & & & & & & \multicolumn{5}{|c|}{ 変化に富んていけ } \\
\hline やりがいがなかった & & & & & & \multicolumn{5}{|c|}{ やりがいがあった } \\
\hline 自分には無関係だった & & & & & & \multicolumn{5}{|c|}{ 自分に関係があった } \\
\hline どラでもいい内容だった & & & & & & \multicolumn{5}{|c|}{ 身につつナたい内容だった } \\
\hline 途中の過程が楽しくなからなた & & & & & & \multicolumn{5}{|c|}{ 途中心過程が相しからた } \\
\hline 自信がつかなかった & & & & & & \multicolumn{5}{|c|}{ 自信がついた } \\
\hline 目標が曖昧だった & & & & & & \multicolumn{5}{|c|}{ 目標がはっぎりててい } \\
\hline 学習を着実に進められひなかった & & & & & & \multicolumn{5}{|c|}{ 学習を着実に進められた } \\
\hline $\begin{array}{r}\text { 自分なりに工夫しながら } \\
\text { 進ゆられなかった }\end{array}$ & & & & & & \multicolumn{5}{|c|}{$\begin{array}{l}\text { 自分ないに工夫しながら } \\
\text { 進かられた }\end{array}$} \\
\hline 不満が残った & & & & & & \multicolumn{5}{|c|}{ やってよかった } \\
\hline すぐには使えそうもない & & & & & & \multicolumn{5}{|c|}{ すぐに使えそうだ } \\
\hline できても認めてもらえなかった & & & & & & \multicolumn{5}{|c|}{ できたら認けてもらえた } \\
\hline 評価に一貫性がなからた & & & & & & \multicolumn{5}{|c|}{ 評価に一貫性があった } \\
\hline
\end{tabular}

Fig. 2-2. Post-questionnaire

「動機づけ効果」は，ARCS 動機づけモデルの 4 分類 (「Attention (注意)」, 「Relevance（関連性）」, $\lceil$ Confidence (自信)」, 「Satisfaction（満足感)」）を 用いた. ${ }^{14)}$ 各分類は 4 項目ずつの下位尺度から構成 され，全 16 項目を 5 段階で，事後に測定を行い，4 分類毎に平均值を算出した。值が大きいほど動機づ け効果が高いことを示す。

「属性」は「性別」,「年齢」,「薬剤師としての勤 務年数」とした.
質問紙は，個人と回答内容が連結しないように無 記名とし，事前事後で一致する番号を付与した。

2-3. 分析方法「観点別評価」については, 事前のゲーム群と講義群の群間を比較し, ベースラ インを評価した後, 各群内の事前事後と, 事後の群 間で比較した。「動機づけ効果」については, 事後 におけるゲーム群と講義群の群間で比較した。

「観点別評価」における各群内の事前事後の比較 には，Wilcoxonの符号付順位和検定を用い，「観点 
4. 空気感染の感染経路別予防策として必要だと思う個人防護具すべてによ印老つけてくだざい (アメリ少疾病管理予防セ゚ター (CDC)ガイドラインの感染別予防策を基準(゙お考えください)

ロ乎袋・グローブロ９5マスクロサージカルマスクロガウン・エブロン

5. 飛沫感染の感染経路別予防策として必要だと思う個人防護具すべてにょ印古つけてください

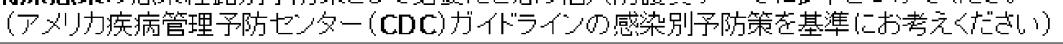

ロ手袋・グローブ ロN95マスク ロサージカルマスク ロガウン・エブロン

6. 接触感染の感染経路別予防策として必要だと思う個人防護具すべてに上印をつけてください (アメリカ疾病管理予防セ゚ンター (CDC)ガイドライノの感染別予防策を基準にお考えください)

ロ乎袋・グローブ ロN95マスク ロサージカルマスク ロガウン・エブロン

7. 水疮瘡(空気感染)に罹患した子どもを親(抗体(-))が看病するとき、気を付けた方が良いにと はありますか?と相談されました。親が使用する個人防護具手洗い以外にどのようとと をアドノ゙イスしますか？下記に記述してくだざ、。

8. ロ放イルス(接触感染)に罹患した乳児の才ムツを交換するとき(䔬口感染)、感染を広けナない ために気を付けた方が良いことはありますか？と聞かれました。個人防護具、手洗い以外に、ど のようなとをアドバイスしまか？下記に記述してぐざ、。

9. 薬局の受け付け事務さんに、イノフルンザに䍜患された患者さんが来局したときに(飛沫感染

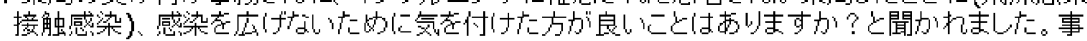
務員さんが使用する個人防護具、手洗い以外に、どのようなとをアドノ゙イスしますか？下記に 記述してくだざい。

10. 今回の研修に関して感想等ごぎいましたら自由にお書きください。

Fig. 2-2. (Continued)

別評価」の事前の群間での比較と,「動機づけ効果」 の群間での比較は, Mann-Whitney の $U$ 検定を用 いた。 また，Wilcoxonの符号付順位和検定及び Mann-Whitney の $U$ 検定について効果量 $(r)$ を算 出した. ${ }^{15)}$

デー夕解析には IBM SPSS Statistics 20 を用い, 有意水準は $\alpha=0.05$ とした.

また，事後の質問紙で得たゲーム又は講義につい ての自由記述式の感想について，内容別に集計を行
つた.

結果

\section{1. 事例収集のためのインタビュ一調査}

1-1. 収集した事例の分類 インタビュー調査 により 72 件の事例が収集され，対応策が設定可能 である事例 55 件を採用した。採用した事例は，体 験したこと 20 件, 質問されたこと 35 件であった. シチュエーション毎に分類したところ，薬局 13 
件，自宅 23 件，学校 9 件，高齢者施設 9 件，避難 所 1 件であった（Fig. 3)。また，感染症毎に分類 した結果, 要因となる感染症が不明だつたものを除 くと，全部で 12 種類となった（ノロウイルス感染 症，季節性インフルエンザ，MRSA 感染症，流行 性角結膜炎, 疥痽, 流行性耳下腺炎, ロタウイルス 感染症，咽頭結膜熱，新型インフルエンザ，結核， ESBL 産生菌感染症，風疹)。シチュエーションに より対応する感染症の種類が異なっており，薬局で は 4 種類, 自宅 7 種類, 学校 5 種類, 高齢者施設 3 種類，避難所 1 種類であった（Table 1)。事例を感 染症毎に，個人防護具，手指消毒，環境消毒の対応 の組み合わせにより分類したところ，全部で 21 パ ターンとなった（Table 2).

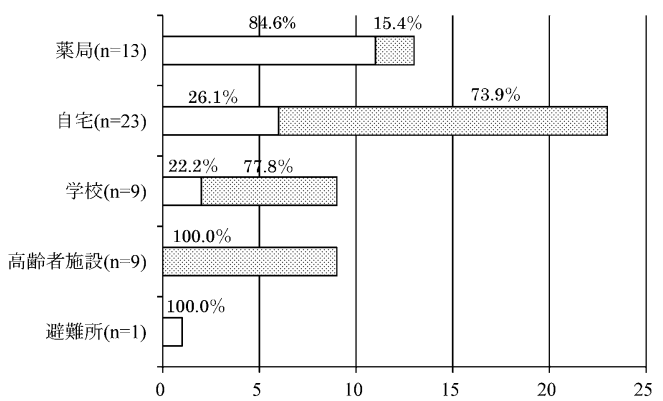

口体験 $(\mathrm{n}=20)$ 曰質問 $(n=35)$

Fig. 3. The Number of Cases of Experiences and Questions by Situation $(n=55)$
1-2. 事例問題の作成とゲーム内容の変更点 ゲームに用いる「CASE カード」は，各感染症と 各対応の組合せ 1 パターンにつき 1 事例とし， 21 問作成した。作成した「CASE カード」の例を Fig. 4 に示す。従来の「SAVE」では，個人防護具と手 指衛生方法が「Key-item」として記載されていたが, 室内環境等の消毒方法に関する事例が得られたこと

Table 1. The Numbers of Cases Classified According to Combination of Infection and Situation $(n=55)$

\begin{tabular}{lrrrcc}
\hline \multirow{2}{*}{ 感染症 } & \multicolumn{5}{c}{ シチュエーション } \\
\cline { 2 - 6 } & 薬局 & 自宅 & 学校 & $\begin{array}{c}\text { 高齢者 } \\
\text { 施設 }\end{array}$ & 避難所 \\
\hline ノロウイルス感染症 & 7 & 8 & 4 & 3 & 1 \\
季節性インフルエンザ & 3 & 2 & 1 & - & - \\
MRSA 感染症 & - & 4 & - & - & - \\
流行性角結膜炎 & - & 3 & 1 & - & - \\
疥癬 & - & - & - & 3 & - \\
流行性耳下腺炎 & 1 & 1 & - & - & - \\
ロタウイルス感染症 & - & 1 & - & - & - \\
咽頭結膜熱 & - & - & 1 & - & - \\
新型インフルエンザ & - & - & 1 & - & - \\
結核 & - & 1 & - & - & - \\
ESBL 産生菌感染症 & - & - & - & 1 & - \\
風疹 & 1 & - & - & - & - \\
不明 & 1 & 3 & 1 & 2 & - \\
\hline & 13 & 23 & 9 & 9 & 1 \\
\hline
\end{tabular}

Table 2. The Numbers of Cases Classified According to Combination of Infection and Infection Control Practice $(n=55)$

\begin{tabular}{|c|c|c|c|c|c|}
\hline \multirow[b]{2}{*}{ 感 染 症 } & \multicolumn{5}{|c|}{ 対 応 の 組 合 せ } \\
\hline & $\begin{array}{c}\text { 個人防護具 } \\
\text { 手指消毒 } \\
\text { 環境消毒 }\end{array}$ & $\begin{array}{c}\text { 個人防護具 } \\
\text { 手指消毒 }\end{array}$ & $\begin{array}{l}\text { 手指消毒 } \\
\text { 環境消毒 }\end{array}$ & 手指消毒 & 環境消毒 \\
\hline ノロウイルス感染症 & 15 & - & - & 2 & 6 \\
\hline 季節性インフルエンザ & 1 & 3 & - & - & 2 \\
\hline MRSA 感染症 & 1 & 1 & - & - & 2 \\
\hline 流行性角結膜炎 & - & - & 2 & - & 2 \\
\hline 疥癬 & - & - & - & - & 3 \\
\hline 流行性耳下腺炎 & - & 2 & - & - & - \\
\hline ロタウイルス感染症 & 1 & - & - & - & - \\
\hline 咽頭結膜熱 & - & - & - & - & 1 \\
\hline 新型インフルエンザ & - & - & - & - & 1 \\
\hline 結核 & - & - & - & - & 1 \\
\hline ESBL 産生菌感染症 & - & - & 1 & - & - \\
\hline 風疹 & - & 1 & - & - & - \\
\hline 不明 & 2 & - & - & - & 5 \\
\hline
\end{tabular}




\section{ノロウイルス小児患者が 薬局の待合室で床に嘔吐した際、 吐物処理の一連の作業の中で、 必要なKey-itemは?} Key-item:【手指衛生(流水下石龄)】【マスク】【グローブ】
【ガウン】【次亜塩素酸Na】

\section{感染経路:【咨口】【接触】}

正解したら声に出して䟽んでみよよう!

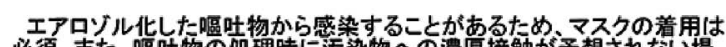
必須。また、嘔吐物の避理時污染物人の濃厚接触が予想されない場

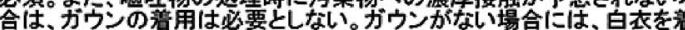
替えるなども有效である。 現状，回ウイルスに関するアルコ一ル擦拭消畫の有効性を示すエビ デンスがないため、流水下石鮯での手洗いが推摇される。 吐物処理の次垔塩素酸ナトリウム濃度は0.1〜 1\%が好ましい。

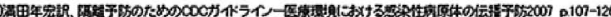
2)

Fig. 4. Created "CASE Card"

から, 消毒薬を追加した.

\section{2. 学習効果の結果}

2-1. 観点別評価 参加者の特性は，ゲーム群 （27 名）は女性が $85.2 \%$ ，男性が $14.8 \%$ ，平均年齢 は $28.9 \pm 6.4$ 歳, 平均勤務年数は $4.7 \pm 4.2$ 年であ り，講義群（32 名）は女性が $78.1 \%$ ，男性が 21.9 $\%$ ，平均年齢は $27.9 \pm 2.9$ 歳，平均勤務年数は 4.9 \pm 3.3 年であった（Table 3)。参加者の特性は 2 群 間で有意な差は示されなかった。

「観点別評価」の事前の評価を 2 群間で比較した ところ，「(1)関心・意欲・態度」の「感染対策に関 心がある」「感染対策に対応できる」の 2 項目は, $p=0.735, p=0.750$ であったが，「感染対策に関わ りたい」は $p=0.030$ と有意な差がみられた。「(2)思 考・判断・表現」,「(3)知識・理解」は $p=0.251, p$ $=0.180$ となり, どちらも有意な差はみられなかっ た

「観点別評価」の各群内での事前事後比較の結果 を Table 4 に示す。「(1)関心・意欲・態度」の 3 項 目，「(2)思考・判断・表現」は，事後が事前に比べ,
Table 3. Characteristics of Subjects

\begin{tabular}{lrrr}
\hline \hline & ゲーム群 $(n=27)$ & 講義群 $(n=32)$ & $p$ \\
\hline 性別 & & & \\
$\quad$ 女性 & 23 名 $(85.2 \%)$ & 25 名 $(78.1 \%)$ & $0.488^{\mathrm{a}}$ \\
$\quad$ 男性 & 4 名 $(14.8 \%)$ & 7 名 $(21.9 \%)$ & \\
年齢 $( \pm$ S.D. $)$ & 28.9 歳 $( \pm 6.36)$ & 27.9 歳 $( \pm 2.85)$ & $0.446^{\mathrm{b}}$ \\
薬剂師として & & & \\
$\begin{array}{l}\text { の勤務年数 } \\
\text { (土S.D.) }\end{array}$ & 4.7 年 $( \pm 4.18)$ & 4.9 年 $( \pm 3.32)$ & $0.840^{\mathrm{b}}$ \\
\hline
\end{tabular}

a The $\chi^{2}$ test was used for group comparisons of sex ratio. ${ }^{\mathrm{b}}$ The Student's $t$-test was used for group comparisons of age and service years to pharmacists.

ゲーム群，講義群ともに有意な上昇を示した（ゲー ム群 : $p=0.025, p=0.003, p=0.003, p<0.001$, 講 義群 : $p=0.020, p=0.005, p<0.001, p<0.001)$.

「(3)知識・理解」は，講義群では事後が事前に比べ 有意な上昇を示し $(p<0.001)$ ，ゲーム群では有意 な差は示されなかった $(p=0.213)$ 。「(3)知識・理解」 の効果量 $(r)$ は，ゲーム群では 0.17 とその効果量 は小さいが, 講義群では $r=0.53$ と効果量が大きか つた.

2-2. 動機づけ効果 「動機づけ効果」の群間 比較の結果を Table 5 に示す。講義群に比べ，ゲー 么群は「Attention (注意)」,「Relevance (関連性)」, $\lceil$ Satisfaction（満足感）」の 3 項目で有意に高い值 を示した $(p<0.001, p=0.002, p=0.002)$ 。「Confidence（自信）」については，群間で有意差は示され なかった $(p=0.708)$ 。また，「Attention (注意)」 では $r=0.60$ と効果量が大きく, 「Confidence（自 信）」では $r=0.05$ と効果量をほとんど示さなかっ た.

2-3. 事後質問紙の感想 事後の自由記述式の 感想を, ゲーム群では 24 名，講義群では 26 名から 得た。ゲーム群では，楽しく学習できたとの記述が $54.2 \%(13 / 24)$ ，知識の定着が難しいとの記述が 50.0\% (12/24)，学習意欲や興味の向上に関する記 述が 25.0\%（6/24）の者から得られた。講義群で は，知識が身に付いた旨の記述が 69.2\% (18/26), 得た知識の実践意欲の向上に関する記述が $26.9 \%$ (7/26)，学習意欲や興味の向上の記述が $11.5 \% （ 3$ /26）の者から得られた.

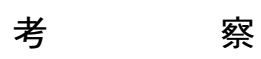

インタビュー調査の結果より，薬局薬剤師は，薬 
Table 4. The Result of the Comparison of Evaluation According to Viewpoint

\begin{tabular}{|c|c|c|c|c|c|}
\hline & 事 & 事 & \multirow{2}{*}{$\mathrm{z}$} & \multirow{2}{*}{$p$} & \multirow{2}{*}{$\begin{array}{c}\text { 効果量 } \\
(r)\end{array}$} \\
\hline & 中央値（四分位範囲） & 中央值（四分位範囲） & & & \\
\hline \multicolumn{6}{|l|}{ ゲーム群（n=27） } \\
\hline \multicolumn{6}{|l|}{ (1) 関心 · 意欲 · 態度 } \\
\hline 感染対策に関心がある & $4.00(4.00-4.00)$ & $4.00(4.00-5.00)$ & -2.24 & 0.025 & 0.31 \\
\hline 感染対策に関わりたい & $4.00(3.00-4.00)$ & $4.00(4.00-4.00)$ & -3.00 & 0.003 & 0.41 \\
\hline 感染対策に対応できる & $2.00(2.00-3.00)$ & $3.00(2.50-3.00)$ & -3.01 & 0.003 & 0.41 \\
\hline (2) 思考 · 判断 · 表現 & $2.00(1.00-4.00)$ & $3.00(2.00-5.00)$ & -3.84 & $<0.001$ & 0.52 \\
\hline （3）知識 $\cdot$ 理解 & $1.00(0.50-1.50)$ & $1.00(1.00-2.00)$ & -1.25 & 0.213 & 0.17 \\
\hline \multicolumn{6}{|l|}{ 講義群 $(n=32)$} \\
\hline 感染対策に関心がある & $4.00(4.00-4.25)$ & $4.00(4.00-5.00)$ & -2.33 & 0.020 & 0.29 \\
\hline 感染対策に関わりたい & $4.00(4.00-4.00)$ & $4.00(4.00-5.00)$ & -2.83 & 0.005 & 0.35 \\
\hline 感染対策に対応できる & $2.00(2.00-3.00)$ & $3.00(3.00-4.00)$ & -4.49 & $<0.001$ & 0.56 \\
\hline （2）思考 - 判断 - 表現 & $1.50(1.00-3.00)$ & $2.00(1.00-4.00)$ & -3.88 & $<0.001$ & 0.51 \\
\hline (3) 知識 - 理解 & $0.00(0.00-1.00)$ & $3.00(1.75-3.00)$ & -4.26 & $<0.001$ & 0.53 \\
\hline
\end{tabular}

The Wilcoxon matched-pairs signed-rank test was used for comparisons between pre- and post-questionnaire data in each group.

Table 5. The Result of the Comparison Motivational Effect

\begin{tabular}{|c|c|c|c|c|c|}
\hline & ゲーム群 $(n=27)$ & 講義群（ $(n=32 ）$ & $U$ & $n$ & 効果量 \\
\hline & 中央値（四分位範囲） & 中央値（四分位範囲） & 0 & $p$ & $(r)$ \\
\hline Attention（注意） & $4.75(4.38-5.00)$ & $4.00(3.50-4.25)$ & 131.0 & $<0.001$ & 0.60 \\
\hline Relevance（関連性） & $4.75(4.50-5.00)$ & $4.25(4.00-4.50)$ & 234.0 & 0.002 & 0.40 \\
\hline Confidence（自信） & $3.50(3.13-3.75)$ & $3.50(3.25-3.50)$ & 408.0 & 0.708 & 0.05 \\
\hline Satisfaction（満足感） & $4.25(4.00-4.50)$ & $3.75(3.50-4.00)$ & 226.5 & 0.002 & 0.41 \\
\hline
\end{tabular}

The Mann-Whitney $U$ test was used for group comparisons.

局において感染症患者と接するだけでなく，看護師 や介護職員，患者家族等から感染対策に関する質問 を受ける機会が多いことが分かった。また，薬局以 外の自宅や学校といつたシチュエーションの方が対 応しなければならない感染症の種類が多いことが示 された，したがって，薬局薬凨師は来局する患者と 接することによる感染リスクの知識だけでなく，他 職種や患者家族等の質問に対応できる知識も必要と 言える，得られた事例に基づいて薬局薬剤師向けに 新たに作成したゲームにより，実践的に感染対策を 学ぶことができると考えられる。

ゲームを用いた研修会を実施し, ゲームによる学 習効果の特性を検証した結果，「観点別評価」の 「(1)関心 ・意欲・態度」において, 事前の群間の比 較では,「感染対策に関わりたい」の項目のみ, ゲー ム群に比べ講義群の方が有意に高かった． 3 項目に
ついてどちらの群においても事前に比べ事後の方が 有意に高く, 効果量は中程度であった.このことか ら, ゲームと講義, それぞれの学習によって学習内 容に関心を持ち, 自ら課題に取り組もうとする意欲 や態度を身に付けられたと考えられる。しかしなが ら, ゲーム群と講義群の割り付けの際に, 性別や年 齢，薬剂師としての勤務年数といつた参加者の特性 について群間で差が生じないよう考慮したが，感染 対策への関心などについても群間で偏りが生じない よう考慮する必要があったと言える。「(2)思考・判 断・表現」は，事前の群間に有意な差はみられず, ゲーム群と講義群どちらも事前に比べ事後の方が有 意に高かつた。 また，各群内での事前事後の比較で は，どちらの群においても大きな効果量を示した. これらのことから, ゲームと講義, それぞれの学習 によって知識・技能を活用して課題を解決すること 
のために必要な思考力・判断力・表現力を身に付け られたと考えられる。「(3)知識・理解」に関しては, 事前の群間に有意な差はみられなかつた．ゲーム群 では事前と事後の比較で有意な差はみられなかった が，講義群では事後が事前に比べ有意な值の上昇を 示した，効果量は，ゲーム群では小さく，講義群で は大きな値を示した．また，事後の感想において， 講義群では知識が身に付いた旨の記載が多くみられ たが，一方，ゲーム群では，知識の定着が難しいと の記載が多くみられた。このことから，習得すべき 知識や重要な概念の理解には, 講義による学習が有 効であると考えられる.

ARCS 動機づけモデルにおいて，「Attention（注 意)」は，知覚レベルでの好奇心や探求心，変化性 など学習者の「注意」の喚起を，「Relevance（関連 性)」は, 学習者の欲求や価值, 目標と結びつけ, 「やりがい」つまり「関連性」の上昇を，「Confidence (自信)」は，成功への自信を学習者に啓発し， 「やればできる」という期待感，つまり「自信」の 側面の刺激を，「Satisfaction（満足感）」は，学習 者の学習意欲を継続させることに役立ち，「やって よかった」という満足感が得られたことを意味す る.16)このモデルに基づく評価結果，「Attention (注意)」「Relevance (関連性)」「Satisfaction（満足 感)」は，講義群よりもゲーム群の方が有意に高い 值を示し，ゲーム群の感想において楽しく学べた旨 の記載が多くみられたことから，講義に比べ，ゲー ムを用いた学習は，学習者の好奇心を喚起し，やり がいを高め，学習意欲を継続させることに役立つと 考えられる．特に「Attention（注意）」では大きな 効果量を示し, 講義とゲームの性質の特徵的な違い であると言える。また，「Confidence（自信)」では, ゲーム群と講義群では効果量をほとんど示さず，有 意な差がみられなかった。 その要因として，今回使 用したゲームは問題を解きながら進んでいくもので あり，問題に正解できなかったことや 30 分という 時間の制約があったため問題を解き切れなかったこ とで，成功への自信が啓発されず自信の側面が刺激 されなかったと考えられる。

本研究では，ゲームは，感染対策に必要な知識や 概念の理解に有意な変化を与えなかった．今回使用 したゲームにおいて，正解者が正解の対応策を読み 上げることで，参加者全員が知識を共有することが
できると考えていたが，自由記述の感想から，1 度 聞いただけでは覚えきれない等の状況が発生してい た可能性が窥える。 このことから，薬局内でゲーム を用いて学習する際は，ゲームを繰り返し行うこと やテキストといつた視覚的な学習資料を補助的に用 い行うなどの改善により，知識向上が期待できると 考える.

本研究により，ゲームを用いた学習と講義による 学習は, 学習への動機づけ効果や知識や理解に与え る影響という点で，それぞれ長所が異なることが示 された。講義による学習は，習得すべき知識や重要 な概念を理解し，体系的に学ぶことに長け，ゲーム を用いた学習は, 動機づけの要因を高め, 学習意欲 の維持につながる可能性がある。このように，それ ぞれの学習による違いや特性が見い出された。この 長所を生かすために，今後は，ゲームと講義を組み 合わせることによる相乗効果を検証し，組み合わせ る際には，その順序について検討することが課題で ある。また，今回はゲーム又は講義の実施直後に効 果測定を行つたが，学習効果の継続性について測定 することも, 今後, 検討する必要があると考える.

謝辞 本研究にご協力頂いた株式会社モレーン コーポレーションの皆様, 日生薬局の皆様, 本研究 に係わって頂いた皆様に心より感謝申し上げます。

\section{REFERENCES}

1) Ministry of Health, Labour and Welfare. "Guidelines for pandemic influenza (A) H1N1) vaccination implementation in contract medical institutions.": 〈http://www. mhlw.go.jp/kinkyu/kenkou/influenza/hourei $/ 2009 / 10 /$ dl/info1013-05.pdf $\rangle$, cited 20 October, 2013.

2) Cabinet Secretariat. "Guidelines for pandemic influenza (A/H1N1).”: 〈http://www.cas.go. $\mathrm{jp} / \mathrm{jp} / \mathrm{seisaku} / \mathrm{ful} / \mathrm{keikaku} / \mathrm{pdf} / \mathrm{gl}$ guideline. pdf $\rangle$, cited 20 October, 2013.

3) Terasawa M., Morimoto I., Ueji T., Yoshimura M., Japanese Journal of Environmental Infections, 27, 57-62 (2012).

4) Okubo K., Clinical Pharmacist, 2(6), 24-29 (2010).

5) Honda R., Nomura K., Japanese Journal of Environmental Infections, 26, 234-238 (2011). 
6) Dobashi R., Utsumi F., Japanese Journal of Environmental Infections, 23, 338-342 (2008) .

7) Telner D., Bujas-Bobanovic M., Chan D., Chester B., Marlow B., Meuser J., Rothman A., Harvey B., Can. Fam. Physician, 56, e345 -e351 (2010).

8) Takeda S., Akamatsu R., Horiguchi I., Marui E., Journal of Health and Welfare Statistics, 57 (1), 36-41 (2010).

9) Morita Y., Fujishima H., Setozaki N., Iwasaki T., Japan Journal of Educational Technology, 35 (Suppl.), 81-84 (2011) .

10) Tominaga A., Kogo C., Okada Y., Transactions of Japanese Society for Information and Systems in Education, 28, 247-252 (2011).

11) Inagaki T., Hirose E., Japan Journal of Educational Technology, 35(Suppl.), 25-28 (2011).
12) Setozaki N., Iwasaki T., Morita Y., Japan Journal of Educational Technology, 36 (2), 81 -90 (2012).

13) Ministry of Education, Culture, Sports, Science and Technology, Nature of learning assessment of students: 〈http://www.mext.go.jp/b_menu/shingi/chukyo/chukyo3/004 /gaiyou/attach/1292216.htm $\rangle$, cited 20 October, 2013.

14) Suzuki K., Nishibuchi A., Yamamoto M., Keller J. M., Information and Systems in Education, 2, 63-69 (2004).

15) Takeuchi O., Mizumoto A., "Gaikokugo Kyouiku Kenkyu Handbook," Shohakusha Publishing Co., Ltd., Tokyo, 2012, pp. 117118.

16) Suzuki K., Japanese Journal of Educational Media Research, 1(1), 50-61 (1995) . 